\title{
Inducible Kiss1 knockdown in the hypothalamic arcuate nucleus suppressed pulsatile secretion of luteinizing hormone in male mice
}

\author{
Shiori MINABE ${ }^{1)}$, Sho NAKAMURA ${ }^{1)}$, Eri FUKUSHIMA ${ }^{1)}$, Marimo SATO ${ }^{1)}$, Kana IKEGAMI ${ }^{2}$, \\ Teppei GOTO $^{3)}$, Makoto SANBO ${ }^{3)}$, Masumi HIRABAYASHI ${ }^{3)}$, Junko TOMIKAWA ${ }^{2)}$, \\ Takuya IMAMURA ${ }^{4)}$, Naoko INOUE2), Yoshihisa UENOYAMA ${ }^{2)}$, Hiroko TSUKAMURA ${ }^{2)}$, \\ Kei-Ichiro MAEDA ${ }^{1)}$ and Fuko MATSUDA ${ }^{1)}$ \\ 1) Department of Veterinary Medical Sciences, The University of Tokyo, Tokyo 113-8657, Japan \\ ${ }^{2)}$ Graduate School of Bioagricultural Sciences, Nagoya University, Nagoya, Aichi 464-8601, Japan \\ ${ }^{3)}$ Center for Genetic Analysis of Behavior, National Institute for Physiological Sciences, Okazaki, Aichi 444-8787, Japan \\ 4) Department of Stem Cell Biology and Medicine, Graduate School of Medical Sciences, Kyushu University, \\ Fukuoka 812-8582, Japan
}

\begin{abstract}
Accumulating evidence suggests that kisspeptin-GPR54 signaling is indispensable for gonadotropin-releasing hormone $(\mathrm{GnRH}) /$ gonadotropin secretion and consequent reproductive functions in mammals. Conventional Kiss 1 knockout (KO) mice and rats are reported to be infertile. To date, however, no study has investigated the effect of inducible central Kiss $1 \mathrm{KO} /$ knockdown on pulsatile gonadotropin release in male mammals. Here we report an in vivo analysis of inducible conditional Kiss 1 knockdown male mice. The mice were generated by a bilateral injections of either adeno-associated virus (AAV) vectors driving Cre recombinase (AAV-Cre) or AAV vectors driving GFP (AAV-GFP, control) into the hypothalamic arcuate nucleus (ARC) of Kiss 1 -floxed male mice, in which exon 3 of the Kiss 1 gene were floxed with loxP sites. Four weeks after the AAV-Cre injection, the mice showed a profound decrease in the both number of ARC Kiss 1 -expressing cells and the luteinizing hormone (LH) pulse frequency. Interestingly, pulsatile LH secretion was apparent 8 weeks after the AAV-Cre injection despite the suppression of ARC Kiss 1 expression. The control Kiss 1 -floxed mice infected with AAV-GFP showed apparent LH pulses and Kiss 1 expression in the ARC at both 4 and 8 weeks after the AAV-GFP injection. These results with an inducible conditional Kiss 1 knockdown in the ARC of male mice suggest that ARC kisspeptin neurons are responsible for pulsatile LH secretion in male mice, and indicate the possibility of a compensatory mechanism that restores $\mathrm{GnRH} / \mathrm{LH}$ pulse generation.
\end{abstract}

Key words: Adeno-associated virus, Gonadotropin, Gonadotropin-releasing hormone, Kiss1, Metastin

(J. Reprod. Dev. 66: 369-375, 2020)

$\mathbf{P}$ ulsatile gonadotropin-releasing hormone $(\mathrm{GnRH})$ /gonadotropin secretion is considered to be indispensable for controlling gonadal functions, such as gametogenesis and steroidogenesis, and has been found in various mammalian species, such as rats [1], guinea pigs [2], pigs [3], sheep [4], goats [5], cows [6], horses [7], and rhesus monkeys [8]. In order to stimulate the production and release of gonadotropin such as luteinizing hormone (LH), a pulsatile pattern of $\mathrm{GnRH}$ release is required at the median eminence (ME) of the mediobasal hypothalamus (MBH) into the hypophyseal portal circulation [4]. A historical experiment by Halasz and Pupp demonstrated that complete deafferentation of the $\mathrm{MBH}$ failed to affect testis weight and structure in male rats, indicating the presence of a hypophysiotropic area within the MBH [9], encompassing a

Received: December 24, 2019

Accepted: March 12, 2020

Advanced Epub: April 26, 2020

(C)2020 by the Society for Reproduction and Development

Correspondence: F Matsuda (e-mail: afukomat@mail.ecc.u-tokyo.ac.jp.)

This is an open-access article distributed under the terms of the Creative Commons Attribution Non-Commercial No Derivatives (by-nc-nd) License. (CC-BY-NC-ND 4.0: https://creativecommons.org/licenses/by-nc-nd/4.0/) center for tonic LH secretion called, "the GnRH/LH pulse generator". This notion was supported by later studies showing that pulsatile LH secretion was kept normally even after complete hypothalamic deafferentation in rats $[1,10]$ and monkeys [11]. In rats and goats, rhythmic electrical bursts of multiple unit activity are accompanied by $\mathrm{LH}$ pulses at regular intervals in the hypothalamic arcuate nucleus (ARC)/ME - an area that contains few, if any, GnRH neuronal cell bodies $[12,13]$. These facts strongly suggest that pulsatile GnRH/ LH secretion is regulated by a pacemaker source (other than $\mathrm{GnRH}$ neurons) located in the ARC.

Kisspeptin-GPR54 signaling is accepted to play a critical role in regulation of reproduction via direct stimulation of GnRH and subsequent gonadotropin release in mammals such as humans [14, 15], primates [16], ruminants [13, 17] and rodents [18]. Male mice and rats with conventional knockout (KO) of the kisspeptin-encoding Kiss 1 gene exhibit atrophied testes, low levels of testosterone, and a suppression of LH pulses [18, 19]. In rodents of both sexes, Kiss 1/ kisspeptin expression is negatively regulated by estradiol and/or testosterone [20-22]. ARC kisspeptin neurons may therefore be a site for the negative feedback action of gonadal steroids that exert an inhibitory effect on LH pulses in both males and females, and are the 
most likely candidate for the $\mathrm{GnRH} / \mathrm{LH}$ pulse generator. However, conditional Kiss $1 \mathrm{KO}$ or knockdown is still necessary to prove this hypothesis, as another population of kisspeptin neurons exists in the anteroventral periventricular nucleus (AVPV) in female rodents. In male rodents, kisspeptin neurons are mainly located only in the ARC since the AVPV Kiss 1 expression is known to be masculinized and/or defeminized by perinatal testosterone surge to cause failure of AVPV Kiss 1 expression as well as occurrence of LH surge [23]. In this context, inducible Kiss $1 \mathrm{KO} /$ knockdown models with male rodents can be used to investigate the definite role of ARC kisspeptin neurons in pulsatile LH secretion.

In this study, we generated inducible ARC-specific Kiss 1 knockdown mice by infecting adeno-associated virus (AAV) vectors driving Cre recombinase (AAV-Cre-GFP) into the brains of Kiss 1 -floxed adult male mice. We analyzed pulsatile LH secretion and determined the long-term effects of ARC Kiss 1 knockdown on male reproductive functions by examining the phenotypes 4 and 8 weeks after the AAV-Cre-GFP injection.

\section{Materials and Methods}

\section{Animals}

Kiss 1-floxed mice were bred in-house from homozygous breeding pairs of Kiss 1 -floxed mice, in which exon 3 of the Kiss 1 gene were floxed with LoxP sites, as described in detail elsewhere [24]. Animals were housed in a controlled environment (14L:10D, lights on at 0500 $\mathrm{h}$, at $22 \pm 2^{\circ} \mathrm{C}$ ) with free access to food and water. Surgical procedures for the animals were performed under isoflurane anesthesia. The study was approved by the Committee on Animal Experiments of the Graduate School of Bioagricultural Sciences, Nagoya University; and the institutional Animal Care and Use Committee of the Graduate School of Agricultural and Life Sciences, The University of Tokyo.

\section{Stereotaxic injection of $A A V$ into the ARC of male mice}

We used a Cre/loxP system to induce region-specific Kiss 1 knockdown. For ARC-specific deletion of Kiss 1, we stereotaxically injected cre-expressing AAV8 (AAV-Cre-GFP, Vector BioLabs, PA, USA) or control AAV8 (AAV-GFP, Vector BioLabs) into the ARC of Kiss 1 -floxed male mice (15-25 weeks old). Each mouse was bilaterally injected with a $26 \mathrm{G}$ stainless cannula, with the tip placed 2.3 and $2.7 \mathrm{~mm}$ posterior, $\pm 0.35 \mathrm{~mm}$ lateral, and $-5.6 \mathrm{~mm}$ ventral to the bregma according to the Paxinos mouse brain atlas [25] (Fig. 1A). We slowly infused $3 \mu \mathrm{L}$ of phosphate-buffered saline (PBS) with $\operatorname{AAV}\left(2 \times 10^{12} \mathrm{GC} / \mathrm{ml}\right)$ into the ARC at a rate of $200 \mathrm{nl} / \mathrm{min}$. After the infusion, the injector was kept in place for an additional 5 min before withdrawal to allow the virus solution to diffuse and to prevent backflow through the needle track. Post-surgery mice were housed individually for up to 8 weeks to allow recovery and sufficient Kiss 1 gene deletion before further experiments.

\section{In vivo analysis of reproductive functions in the inducible} ARC Kiss1 knockdown male mice

Pulsatile LH secretions were analyzed by frequent blood sampling in free-moving male mice as described previously [26]. Mice were bilaterally castrated one week before frequent blood sampling to detect LH pulses without the negative feedback effects (if any) of
A
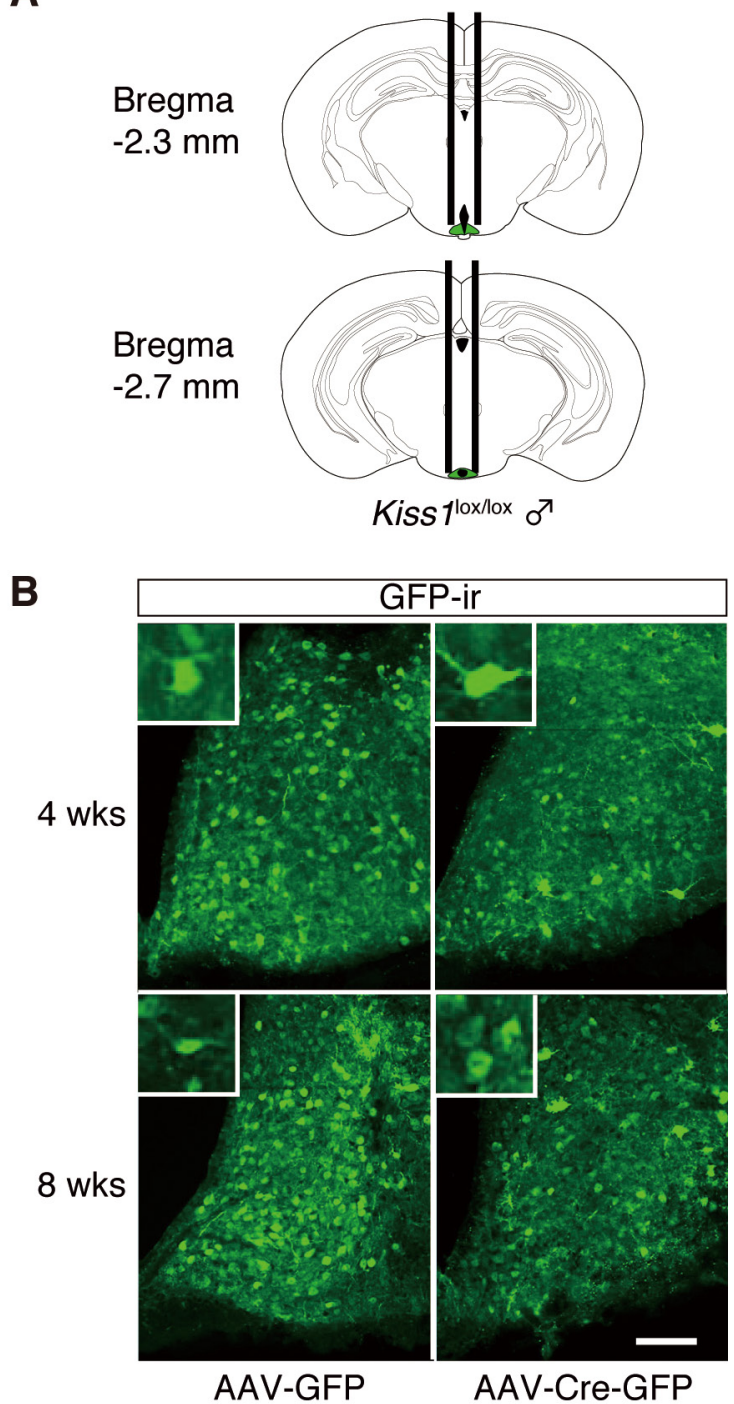

Fig. 1. Transgene expression in the arcuate nucleus (ARC) of Kiss 1floxed (Kiss $1^{\text {lox/lox }}$ ) male mouse brain 4 or 8 weeks after the injection of adeno-associated virus (AAV) vector into the ARC. (A) Schematic representation of the site of injection (green, the ARC) adapted from the Paxinos and Franklin [25] mouse brain atlas. (B) Representative photomicrographs showing the distribution of GFP immunoreactivity (GFP-ir) in the ARC of a Kiss 1-floxed male mouse injected with AAV-GFP or AAV-CreGFP. Insets: GFP-ir cells at a higher magnification. Scale bar, $100 \mu \mathrm{m}$. AAV-GFP, Kiss 1 -floxed male mice transduced with AAV-GFP in the ARC; AAV-Cre-GFP, Kiss 1 -floxed male mice transduced with AAV-Cre-GFP in the ARC; 4 wks, Kiss l-floxed male mice analyzed 4 weeks after AAV injection; 8 wks, floxed male mice analyzed in 8 weeks after AAV injection.

steroid hormones. To analyze plasma testosterone concentrations, blood samples $(50 \mu 1)$ were obtained from the caudal vein under anesthesia immediately before castration. The testes were weighed, fixed with $4 \%$ paraformaldehyde PBS solution, and their paraffin sections $(4 \mu \mathrm{m})$ were histologically examined under a microscope 
after general staining with hematoxylin-eosin (HE). To quantify testes morphology, two cross-sections were made from the middle of the testis. Tubular diameters were imaged at $4 \times$ with a light microscope (BX50; Olympus, Tokyo, Japan) and analyzed across their shortest axis from cross-sectional profiles using ImageJ software (National Institutes of Health, Bethesda, MD, USA). To analyze the percentage of mature spermatids in total tubules, seminiferous tubules containing step 16 spermatids (elongated spermatids that line the lumen [27]) were counted under a $10 \times$ ocular and $20 \times$ objective of a light microscope (BX50; Olympus).

Each animal then received an indwelling atrial cannula made of silicon tubing (internal diameter, $0.5 \mathrm{~mm}$; outer diameter, $1.0 \mathrm{~mm}$; length, $22 \mathrm{~cm}$; Shin-Etsu Polymer, Tokyo, Japan) through the right jugular vein, 2 days before blood sampling. In order to determine LH pulses, blood samples $(20 \mu \mathrm{l})$ were collected through the intra-atrial cannula at 3-min intervals for $1 \mathrm{~h}$ starting at $1300 \mathrm{~h}$. To keep the hematocrit values constant, each blood sample was replaced with an equivalent volume of washed red blood cells obtained from other ICR strain wild-type mice. Plasma was separated by centrifugation at $3,000 \mathrm{rpm}$ for $10 \mathrm{~min}$ at $4^{\circ} \mathrm{C}$, and $10 \mu \mathrm{l}$ aliquots were stored at $-30^{\circ} \mathrm{C}$ until the LH assay. To confirm no changes in their estimated total body fluid volume, the body weights of each mouse was measured before and after the blood sampling.

\section{Visualization of Kiss1 and GFP}

Castrated Kiss 1 -floxed mice treated with AAV-Cre-GFP or AAVGFP in the ARC were deeply anesthetized with sodium pentobarbital and perfused with $0.05 \mathrm{M} \mathrm{PBS}$, followed by $4 \%$ paraformaldehyde$\mathrm{PB}$ through the right atrium, clamping the thoracic vena cava to prevent fixative from perfusing the lower body. Brains were removed immediately, postfixed in the same fixative overnight at $4{ }^{\circ} \mathrm{C}$, and then immersed in $30 \%$ sucrose in $0.05 \mathrm{M} \mathrm{PB}$ at $4^{\circ} \mathrm{C}$. Serial coronal sections ( $50 \mu \mathrm{m}$ in thickness) of the hypothalamus containing the ARC were obtained using a cryostat. Every fourth section of the whole ARC (1.23-2.79 $\mathrm{mm}$ posterior to the bregma) - taken from each mouse according to the brain atlas [25] — was subjected to histological analysis for Kiss 1 and/or GFP expression.

Mouse Kiss 1 mRNA expression in the ARC was detected by freefloating in situ hybridization using specific digoxigenin (DIG)-labeled probes, as described elsewhere [28]. DIG-labeled anti-sense cRNA probes for mouse Kiss 1 (position 60-372; GenBank accession no. NM_178260) were synthesized by in vitro transcription from the mouse hypothalamic cDNA using a DIG-RNA labeling kit (Boehringer Mannheim GmbH, Mannheim, Germany). To detect the DIG-labeled Kiss 1 probe after hybridization, alkaline phosphatase-conjugated anti-DIG antibody (1:1000; Roche Diagnostics, Indianapolis, IN, USA) and a chromagen solution ( $337 \mu \mathrm{g} / \mathrm{ml} 4$-Nitroblue tetrazolium chloride, $175 \mu \mathrm{g} / \mathrm{ml}$ 5-Bromo-4-chloro-3-indoyl-phosphate) were used. The sections were mounted and examined by an optical microscope (BX51; Olympus). Specificity of Kiss 1 probes was confirmed by the absence of signal in ARC sections hybridized with the sense Kiss 1 cRNA probe (data not shown), while Kiss 1 expression was detected exclusively with anti-sense probe.

To visualize GFP, the sections were incubated with anti-GFP chicken polyclonal antibody (1:2000, ab13970, Abcam, Cambridge, UK) and then incubated with secondary antibodies conjugated with
Alexa Fluor 488 (1:800, A21202, Invitrogen, Carlsbad, CA, USA). Fluorescence images were obtained with laser scanning confocal microscopy (LSM5 Pascal; Carl Zeiss, Oberkochen, Germany).

\section{LH and testosterone assays}

Plasma LH concentrations were determined with a mouse LH radioimmunoassay kit provided by the National Hormone and Peptide Program (Bethesda, MD, USA). LH concentrations were expressed in terms of NIDDK mouse LH-RP AFP-5306A. The least detectable level was $0.78 \mathrm{ng} / \mathrm{ml}$ for $10 \mu \mathrm{l}$ plasma, and the intra- and inter-assay coefficients of variation were $5.3 \%$ at $4.9 \mathrm{ng} / \mathrm{ml}$ and $10.7 \%$ at 2.03 $\mathrm{ng} / \mathrm{ml}$, respectively.

Plasma testosterone concentrations were determined by an enzyme immunoassay as described previously [29]. Testosterone was measured after diethyl-ether extraction, followed by an overnight incubation with sheep anti-testosterone antibody (1: 60,000, GDN \#250, kindly donated by Dr GD Niswander, Colorado University, CO, USA) at $4^{\circ} \mathrm{C}$ in 96 -well plates pre-coated with rabbit anti-sheep IgG antibody $(0.5 \mu \mathrm{g} / 100 \mu \mathrm{l} /$ well, \#613-4128, Rockland Immunochemicals, PA. USA). After incubation with horseradish peroxidase (HRP)-labeled testosterone for $4 \mathrm{~h}$ at $4^{\circ} \mathrm{C}, \mathrm{HRP}$ activity was visualized using a 3, 3', 5, 5'-tetrame-thylbenzidine substrate. The least detectable level was $0.125 \mathrm{ng} / \mathrm{ml}$ for $10 \mu \mathrm{l}$ plasma, and the intra- and inter-assay coefficients of variation were $2.6 \%$ and $13.3 \%$ at $5.08 \mathrm{ng} / \mathrm{ml}$, respectively.

\section{Data analysis and statistics}

To quantify the number of Kiss 1-expressing cells, every fourth section of the whole ARC region was used for counting. The numbers of Kiss 1-expressing cells in the ARC were statistically analyzed. LH pulses were identified by the PULSAR computer program [30] as previously described [31]. Statistical differences between AAV-GFP and AAV-Cre-GFP groups in terms of testicular weight, tubular diameters, percentage of mature spermatids in total tubules, each $\mathrm{LH}$ pulse parameter, and the number of cells expressing Kiss 1 mRNA were determined by Student's $t$-tests. Statistical difference in plasma testosterone levels between the AAV-GFP and AAV-Cre-GFP groups was determined by the Mann-Whitney $U$ test.

\section{Results}

\section{Confirmation of region-specific Kiss1 knockdown in the ARC of adult male mice}

Kiss 1-floxed male mice were bilaterally injected with AAV8 into the middle (Fig. 1A, upper panel) and posterior (Fig. 1A, lower panel) part of the ARC. Fig. 1B shows the immunohistochemical localization of GFP immunoreactivity (ir) in the ARC of representative Kiss l-floxed male mice injected with AAV-GFP or AAV-Cre-GFP. GFP-ir cells were observed in the ARC in both AAV-GFP and AAV-Cre-GFP groups at 4 or 8 weeks after the injection.

Fig. 2A shows Kiss 1 -expressing cells in the ARC of representative Kiss 1 -floxed male mice injected AAV-GFP or AAV-Cre-GFP. Few Kiss 1-expressing cells were found in the ARC of AAV-Cre-GFPinjected mice, while such cells were abundant in control mice (Fig. 2A). The numbers of Kiss 1-expressing cells in AAV-Cre-GFP mice $(468 \pm 57$ cells at 4 weeks and $331 \pm 34$ cells at 8 weeks $)$ were significantly lower $(\mathrm{P}<0.05$ at 4 weeks and $\mathrm{P}<0.01$ at 8 weeks, 


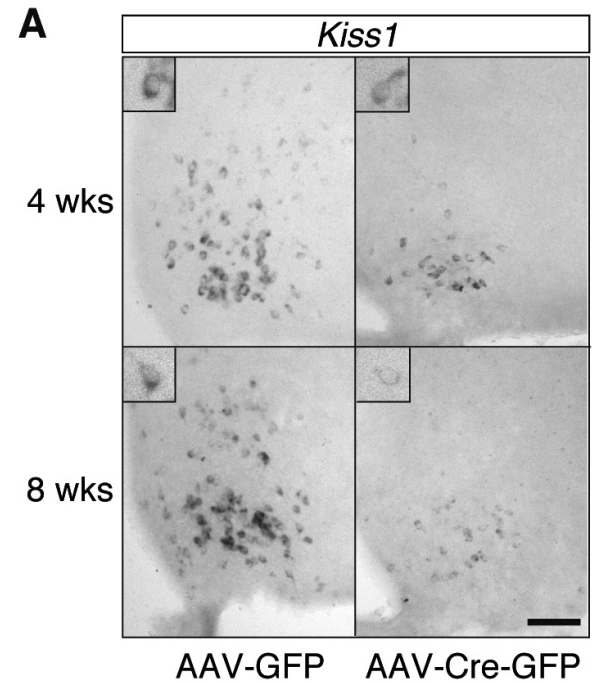

B

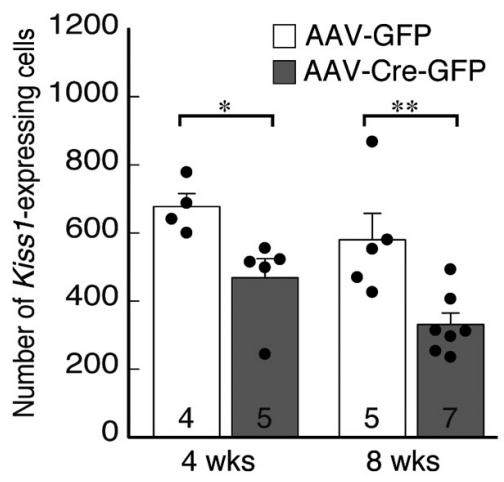

Fig. 2. Inducible knockdown of Kiss 1 expression in the arcuate nucleus (ARC) of castrated male Kiss 1 -floxed mice. (A) Representative photomicrographs showing the distribution of Kiss 1 mRNA in the ARC of each group. Scale bar, $100 \mu \mathrm{m}$. (B) Number of Kiss 1 -expressing cells in the ARC, with the mean \pm SEM and individual data points overlaid on the bar charts. The numbers in or on each column indicate the sample size of the group. $* \mathrm{P}<0.05 ; * * \mathrm{P}<0.01$ ( $v s$. AAV-GFP-injected controls, Student's $t$-test). Abbreviations are the same as in Fig. 1.

Student's $t$-test) compared to those in the corresponding groups of control mice $(678 \pm 38$ cells at 4 weeks and $580 \pm 77$ cells at 8 weeks) (Fig. 2B).

\section{Suppression of LH pulses by the inducible ARC Kiss1}

knockdown in male mice

Fig. 3A shows the profiles of LH release in representative Kiss 1floxed male mice in each group. Apparent LH pulses were found in control Kiss 1 -floxed mice at both 4 and 8 weeks after AAV-GFP injection, but pulsatile LH release was profoundly suppressed in Kiss 1 -floxed mice 4 weeks after AAV-Cre-GFP injection (Fig. 3A). In contrast, LH pulses were normal in Kiss 1 -floxed mice 8 weeks after the injection (Fig. 3A). The frequency of LH pulses was significantly different between AAV-Cre-GFP-injected mice and their control counterparts at 4 weeks after injection $(\mathrm{P}<0.05)$, but not at 8 weeks (Fig. 3B). The mean and baseline LH levels, as well as the amplitude of $\mathrm{LH}$ pulses in AAV-Cre-GFP-injected mice were comparable to those in control mice (Fig. 3B).

\section{The effect of inducible ARC Kiss1 knockdown on testis} morphology and plasma testosterone levels in male mice

Fig. 4A shows representative photomicrographs of HE-stained testes obtained from AAV-GFP- or AAV-Cre-GFP-injected Kiss 1 -floxed male mice 4 or 8 weeks after the injection. No obvious changes in testis morphology were observed between AAV-Cre-GFP-injected mice and control mice (Fig. 4A). Plasma testosterone levels of AAV-Cre-GFP-injected Kiss 1 -floxed mice tended to be lower ( $\mathrm{P}=$ 0.1 ) at 4 weeks after the AAV injection, but no significant difference was found between groups (Fig. 4B, left). Plasma testosterone levels at 8 weeks after injection showed no significant difference between groups. Testicular weights were comparable between the control and AAV-Cre-GFP groups at both 4 and 8 weeks after injection (Fig. $4 \mathrm{~B}$, right). Additionally, both seminiferous tubule diameters and percentage of mature spermatids in total tubules were comparable between the control and AAV-Cre-GFP groups at both 4 and 8 weeks after injection (Fig. 4C). Body weight also remained unaffected in AAV-Cre-GFP-injected mice 4 weeks (AAV-GFP: $47.48 \pm 2.01 \mathrm{~g}$ vs. AAV-Cre-GFP: $46.68 \pm 1.76 \mathrm{~g}$ ) or 8 weeks (AAV-GFP: $46.33 \pm$ $3.00 \mathrm{~g} v s$. AAV-Cre-GFP: $49.97 \pm 2.77 \mathrm{~g}$ ) after injection.

\section{Discussion}

This study demonstrates that the inducible ARC Kiss 1 knockdown male mice exhibited suppression of pulsatile LH release, suggesting that the ARC kisspeptin neurons might serve as a GnRH/LH pulse generator in mice. These results are consistent with our previous study that reported complete suppression of pulsatile LH secretion in rats after a conventional Kiss $1 \mathrm{KO}$ [18]. An advantage of the current inducible Kiss 1 knockdown male mice model is that it minimizes the potential confounding effect of developmental compensation. Although technical limitations resulted in the acute deletion of only $30 \%$ of total ARC Kiss 1 expression, the results indicate that this partial deletion was sufficient for significant suppression of $\mathrm{GnRH} / \mathrm{LH}$ pulse generation. Accumulating evidence suggests that neurokinin $\mathrm{B}(\mathrm{NKB})$ and dynorphin A - expressed in the ARC kisspeptin neurons - facilitate and inhibit neuronal activity, respectively, and hence generate the rhythmic activity of the neurons [13]. Our results - demonstrating that targeting only Kiss 1 knockdown lowered LH pulse frequency — suggest that in addition to these neuropeptides, kisspeptin-GPR54 signaling may also be involved in the GnRH/LH pulse generation. This notion is also supported by previous studies showing that administration of kisspeptin increases LH pulse frequency in ewes and humans, in which NKB inactivation significantly lowers the LH pulse frequency [32, 33]. GPR54 expression was abundantly detected in close proximity to the ARC kisspeptin neurons, but not in the ARC kisspeptin-ir cells in female rats [34], suggesting that ARC kisspeptin neurons might construct neuronal circuits with other GPR54-expressing cells in order to affect $\mathrm{GnRH} / \mathrm{LH}$ pulse generation.

In this study, testicular morphology and plasma testosterone 
A

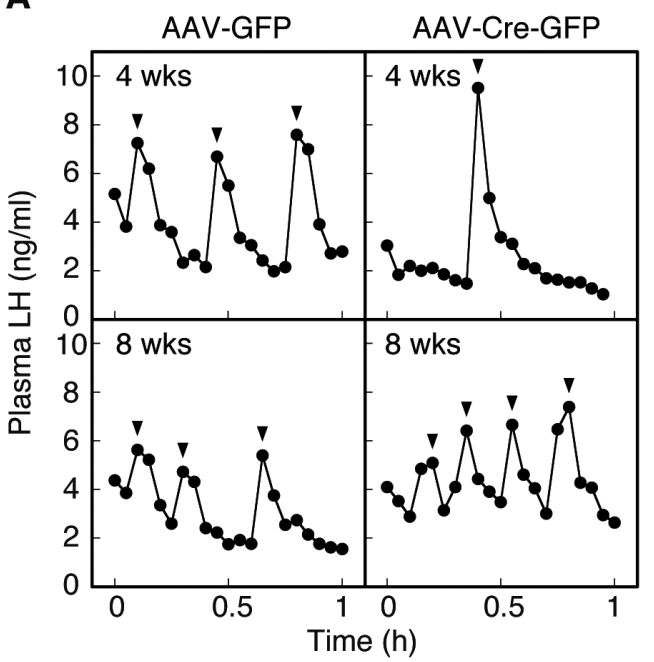

B

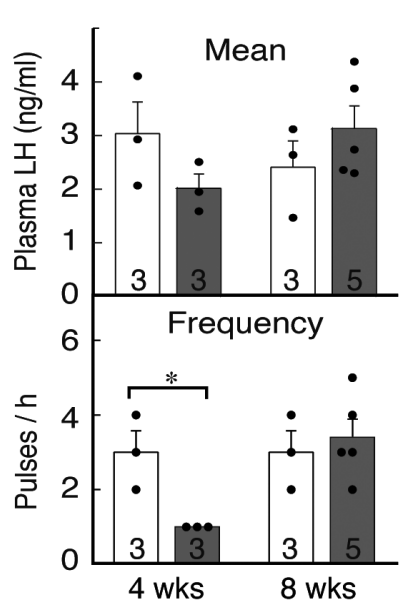

$\square$ AAV-GFP

AAV-Cre-GFP
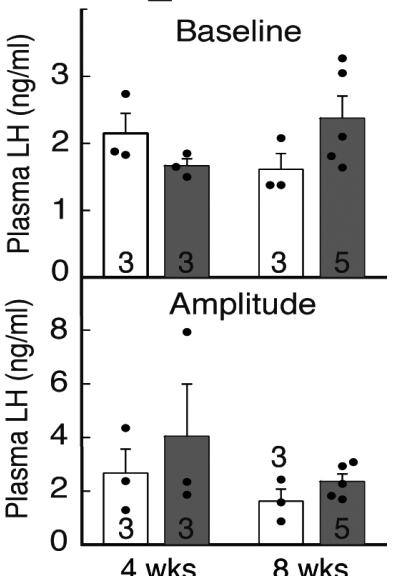

Fig. 3. Effect of AAV-GFP or AAV-Cre-GFP injection on pulsatile luteinizing hormone (LH) secretion in castrated male Kiss 1-floxed mice. (A) Plasma LH profiles in representative animals from each group. Blood samples were collected every $3 \mathrm{~min}$ for $1 \mathrm{~h}$ a week after the castration. Arrowheads indicate the peaks of LH pulses as identified by the PULSAR computer program. (B) Mean and baseline LH concentrations, and the frequency and amplitude of LH pulses were calculated for a 1-h sampling period. Bar charts portray the mean \pm SEM with individual data points overlaid. The numbers in or on each column indicate the sample size of the group. ${ }^{*} \mathrm{P}<0.05$ ( $v$ s. AAV-GFP-injected controls, Student's $t$-test). Abbreviations are the same as in Fig. 1.

levels were comparable between control and AAV-Cre-GFP groups despite a reduction of pulsatile LH secretion in Kiss 1 -floxed mice 4 weeks after the AAV injection. The discrepancy between LH pulses and testicular functions in the inducible Kiss 1 knockdown mice could be because their mean and baseline LH levels and amplitude of LH pulses were comparable to the control groups. GnRH/LH pulsatility is essential for pituitary responsiveness to GnRH because gonadotropin synthesis and GnRH receptor gene expression in the pituitary gonadotroph depend on the pulsatile pattern of $\mathrm{GnRH}$ signals $[35,36]$, whereas testicular function could be maintained by a certain plasma level of LH. This interpretation is supported by the fact that hypophysectomized male rats injected with LH twice daily show an increase in plasma testosterone levels [37]. Since the inducible Kiss 1 knockdown mice showed significant suppression of ARC Kiss 1 expression even though $70 \%$ of ARC kisspeptin neurons remained, the remaining kisspeptin neurons might be sufficient to maintain testicular functions.

Interestingly, pulsatile LH secretion was detected 8 weeks after the AAV-Cre injection despite the suppression of ARC Kiss 1 expression, indicating the possibility of a compensatory mechanism against the reduction of kisspeptin neurons. Complete Kiss $1 \mathrm{KO}$ showed hypogonadotropic hypogonadism in male mice [19], and several mice models with conventional Kiss 1 KO have also shown that a compensatory mechanism during the developmental period may rescue reproductive functions in global Kiss $1 \mathrm{KO}$ mice [38, 39]. While it is still unclear how LH pulses in the inducible Kiss 1 knockdown mouse model are rescued; we suggest two possible explanations. First, the residual kisspeptin neurons in this study may have acquired full functionality as a GnRH pulse generator. This interpretation is supported by a previous study which determined that male homozygous $\mathrm{Kiss} 1^{\mathrm{Cre} / \mathrm{Cre}}$ mice with only $5 \%$ of the normal Kiss 1 transcript can sire normal-sized litters [40]. Suppression of LH pulses 4 weeks after the AAV-Cre injection suggests that residual kisspeptin neurons reconstruct their neuronal network for GnRH pulse generator. Such a neuronal network reconstruction in adulthood has been reported in GnRH neurons; transplants of GnRH neurons into GnRH-deficient mice increased gonadotropin levels, gonadal development, and spermatogenesis [41]. Second, the reduction of Kiss 1 may be compensated by systems other than kisspeptin neurons, which modulate GnRH secretions. Seminara et al. suggested the existence of a kisspeptin-independent GnRH-stimulatory pathway by showing that treatment with a GnRH antagonist significantly decreased serum gonadotropin levels and spermatogenesis in Kiss 1 KO mice with hypogonadotropic hypogonadism compared to vehicle treatment [38]. Thus, these compensatory changes in the hypothalamic $\mathrm{GnRH} / \mathrm{LH}$ pulse generation system might cause LH pulse recovery, and subsequently induce spermatogenesis.

Our results demonstrate that the ARC kisspeptin neurons are responsible for pulsatile LH secretion in male mice, despite our technical limitations that were only able to achieve partial knockdown of ARC Kiss 1 expression. Our results also show possibility of potential compensatory mechanism to restore $\mathrm{GnRH} / \mathrm{LH}$ pulse generation in adulthood. This study improves our understanding of how a highly redundant system of GnRH/LH pulse generation with central kisspeptin ensures reproductive success during adulthood in male mice. 

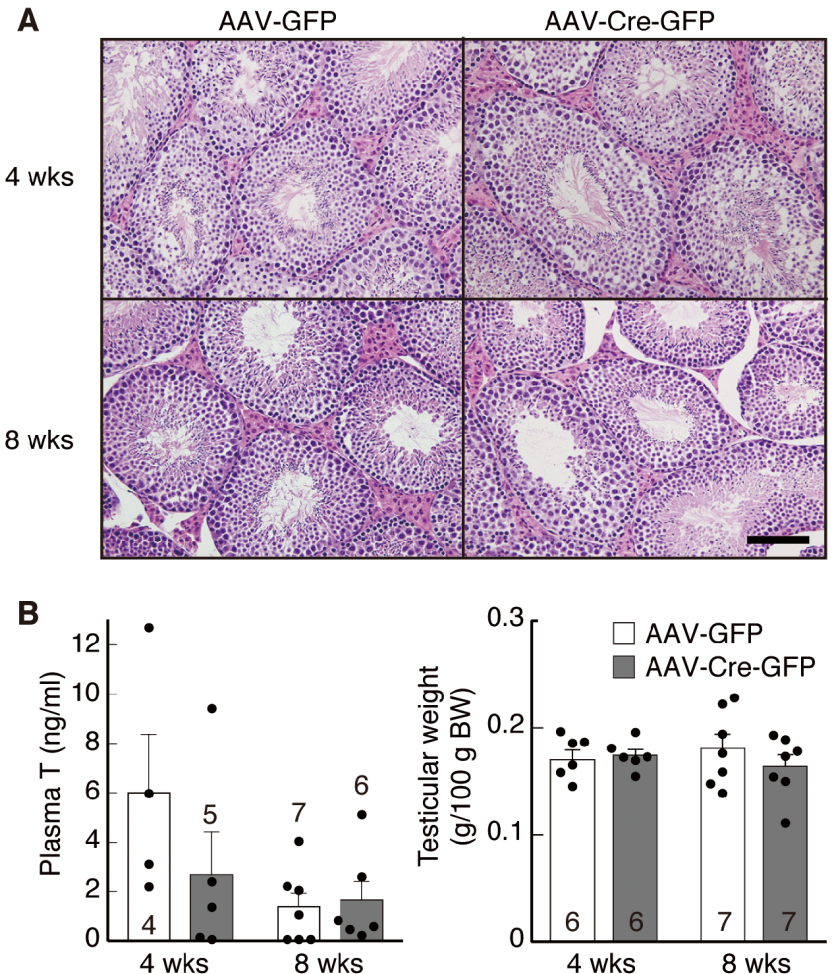

C
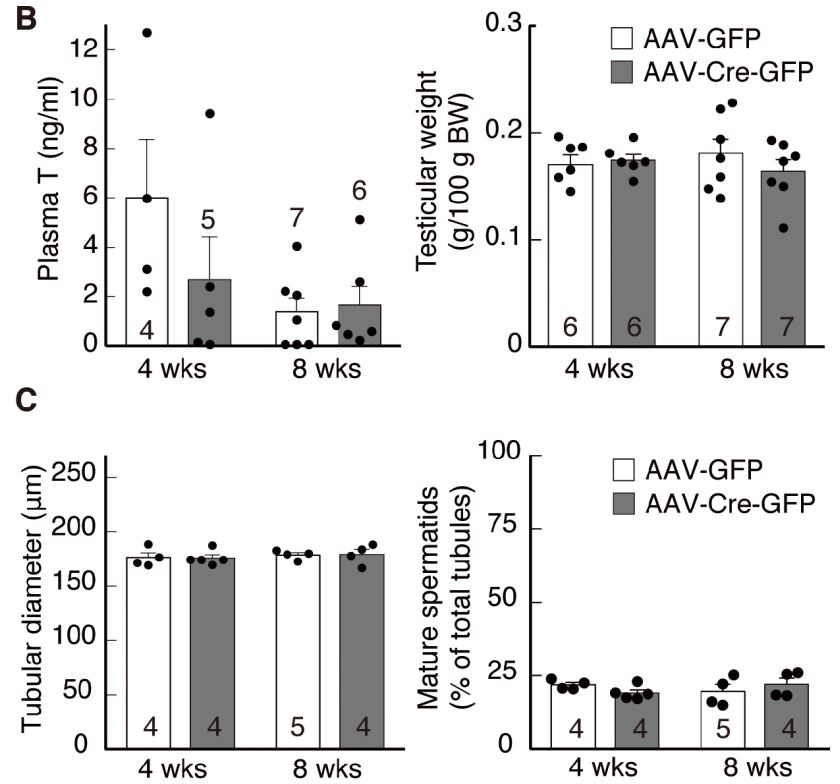

Fig. 4. Effect of AAV-GFP or AAV-Cre-GFP injection on testicular functions in male Kiss 1 -floxed mice. (A) Photomicrographs of testicular sections stained by hematoxylin and eosin in a representative animal from each group. Insets: Kiss 1-expressing cells at a higher magnification. Scale bar, $100 \mu \mathrm{m}$. (B) Plasma testosterone (T) levels (left) and testicular weights (right) in each group. (C) Tubular diameters (left) and percentage of mature spermatids in total tubules (right) in each group. Bar charts portray the mean \pm SEM with individual data points overlaid. Numbers in or on each column indicate the sample size of the group. Abbreviations are the same as in Fig. 1.

Conflict of Interests: The authors have nothing to disclose.

\section{Acknowledgments}

We thank Drs Kazuyuki Uchida and James K Chambers (The University of Tokyo) for technical support with the histological analysis of testes. We also thank the National Hormone and Peptide Program, National Institute of Diabetes and Digestive and Kidney Diseases, and are indebted to Dr AF Parlow for providing the LH assay kit and to Drs GR Merriam and KW Wachter for the PULSAR computer program. The LH radioimmunoassay was performed at The University of Tokyo Radioisotope Center. This work was supported in part by the Grants-in-Aid for Scientific Research (Grant 18H03973 to HT, Grant 16K07987 to NI, and Grant 16H06206 to FM) from the Japanese Ministry of Education, Culture, Sports, Science and Technology and the Cooperative Study Program of National Institute for Physiological Sciences.

\section{References}

1. Ohkura S, Tsukamura H, Maeda K. Effects of various types of hypothalamic deafferentation on luteinizing hormone pulses in ovariectomized rats. J Neuroendocrinol 1991; 3: 503-508. [Medline] [CrossRef]

2. Gore AC, Terasawa E. Neural circuits regulating pulsatile luteinizing hormone release in the female guinea-pig: opioid, adrenergic and serotonergic interactions. J Neuroendocrinol 2001; 13: 239-248. [Medline] [CrossRef]

3. Noguchi M, Yoshioka K, Kaneko H, Iwamura S, Takahashi T, Suzuki C, Arai S, Wada Y, Itoh S. Measurement of porcine luteinizing hormone concentration in blood by time-resolved fluoroimmunoassay. J Vet Med Sci 2007; 69: 1291-1294. [Medline] [CrossRef]

4. Moenter SM, Brand RM, Midgley AR, Karsch FJ. Dynamics of gonadotropinreleasing hormone release during a pulse. Endocrinology 1992; 130: 503-510. [Medline] [CrossRef]

5. Tanaka T, Ozawa T, Hoshino K, Mori Y. Changes in the gonadotropin-releasing hormone pulse generator activity during the estrous cycle in the goat. Neuroendocrinology 1995; 62: 553-561. [Medline] [CrossRef]

6. Rahe CH, Owens RE, Fleeger JL, Newton HJ, Harms PG. Pattern of plasma luteinizing hormone in the cyclic cow: dependence upon the period of the cycle. Endocrinology 1980; 107: 498-503. [Medline] [CrossRef]

7. Fitzgerald BP, I'Anson H, Loy RG, Legan SJ. Evidence that changes in LH pulse frequency may regulate the seasonal modulation of $\mathrm{LH}$ secretion in ovariectomized mares. J Reprod Fertil 1983; 69: 685-692. [Medline] [CrossRef]

8. Dierschke DJ, Bhattacharya AN, Atkinson LE, Knobil E. Circhoral oscillations of plasma LH levels in the ovariectomized rhesus monkey. Endocrinology 1970; 87: 850-853. [Medline] [CrossRef]

9. Halász B, Pupp L. Hormone secretion of the anterior pituitary gland after physical interruption of all nervous pathways to the hypophysiotrophic area. Endocrinology 1965; 77: 553-562. [Medline] [CrossRef]

10. Blake CA, Sawyer CH. Effects of hypothalamic deafferentation on the pulsatile rhythm in plasma concentrations of luteinizing hormone in ovariectomized rats. Endocrinology 1974; 94: 730-736. [Medline] [CrossRef]

11. Krey LC, Butler WR, Knobil E. Surgical disconnection of the medial basal hypothalamus and pituitary function in the rhesus monkey. I. Gonadotropin secretion. Endocrinology 1975; 96: 1073-1087. [Medline] [CrossRef]

12. Kawakami M, Uemura T, Hayashi R. Electrophysiological correlates of pulsatile gonadotropin release in rats. Neuroendocrinology 1982; 35: 63-67. [Medline] [CrossRef]

13. Wakabayashi Y, Nakada T, Murata K, Ohkura S, Mogi K, Navarro VM, Clifton DK, Mori Y, Tsukamura H, Maeda K, Steiner RA, Okamura H. Neurokinin B and dynorphin A in kisspeptin neurons of the arcuate nucleus participate in generation of periodic oscillation of neural activity driving pulsatile gonadotropin-releasing hormone secretion in the goat. J Neurosci 2010; 30: 3124-3132. [Medline] [CrossRef]

14. Seminara SB, Messager S, Chatzidaki EE, Thresher RR, Acierno JS Jr, Shagoury JK, Bo-Abbas Y, Kuohung W, Schwinof KM, Hendrick AG, Zahn D, Dixon J, Kaiser UB, Slaugenhaupt SA, Gusella JF, O'Rahilly S, Carlton MB, Crowley WF Jr, Aparicio SA, Colledge WH. The GPR54 gene as a regulator of puberty. $N$ Engl J Med 2003; 349: 1614-1627. [Medline] [CrossRef]

15. de Roux N, Genin E, Carel JC, Matsuda F, Chaussain JL, Milgrom E. Hypogonadotropic hypogonadism due to loss of function of the KiSS1-derived peptide receptor GPR54. Proc Natl Acad Sci USA 2003; 100: 10972-10976. [Medline] [CrossRef]

16. Keen KL, Wegner FH, Bloom SR, Ghatei MA, Terasawa E. An increase in kisspeptin-54 release occurs with the pubertal increase in luteinizing hormone-releasing hormone-1 release in the stalk-median eminence of female rhesus monkeys in vivo. Endocrinology 2008; 149: 4151-4157. [Medline] [CrossRef]

17. Ohkura S, Takase K, Matsuyama S, Mogi K, Ichimaru T, Wakabayashi Y, Uenoyama Y, Mori Y, Steiner RA, Tsukamura H, Maeda KI, Okamura H. Gonadotrophin-releasing hormone pulse generator activity in the hypothalamus of the goat. $J$ Neuroendocrinol 2009; 21: 813-821. [Medline] [CrossRef] 
18. Uenoyama Y, Nakamura S, Hayakawa Y, Ikegami K, Watanabe Y, Deura C, Minabe S, Tomikawa J, Goto T, Ieda N, Inoue N, Sanbo M, Tamura C, Hirabayashi M, Maeda K, Tsukamura H. Lack of pulse and surge modes and glutamatergic stimulation of LH release in Kiss1 knockout rats. J Neuroendocrinol 2015; 27: 187-197. [CrossRef]

19. d'Anglemont de Tassigny X, Fagg LA, Dixon JP, Day K, Leitch HG, Hendrick AG, Zahn D, Franceschini I, Caraty A, Carlton MB, Aparicio SA, Colledge WH. Hypogonadotropic hypogonadism in mice lacking a functional Kiss1 gene. Proc Natl Acad Sci USA 2007; 104: 10714-10719. [Medline] [CrossRef]

20. Smith JT, Cunningham MJ, Rissman EF, Clifton DK, Steiner RA. Regulation of Kiss 1 gene expression in the brain of the female mouse. Endocrinology 2005; 146: 3686-3692. [Medline] [CrossRef]

21. Smith JT, Dungan HM, Stoll EA, Gottsch ML, Braun RE, Eacker SM, Clifton DK, Steiner RA. Differential regulation of KiSS-1 mRNA expression by sex steroids in the brain of the male mouse. Endocrinology 2005; 146: 2976-2984. [Medline] [CrossRef]

22. Adachi S, Yamada S, Takatsu Y, Matsui H, Kinoshita M, Takase K, Sugiura H, Ohtaki T, Matsumoto H, Uenoyama Y, Tsukamura H, Inoue K, Maeda K. Involvement of anteroventral periventricular metastin/kisspeptin neurons in estrogen positive feedback action on luteinizing hormone release in female rats. J Reprod Dev 2007; 53: 367-378. [Medline] [CrossRef]

23. Homma T, Sakakibara M, Yamada S, Kinoshita M, Iwata K, Tomikawa J, Kanazawa T, Matsui H, Takatsu Y, Ohtaki T, Matsumoto H, Uenoyama Y, Maeda K, Tsukamura H. Significance of neonatal testicular sex steroids to defeminize anteroventral periventricular kisspeptin neurons and the GnRH/LH surge system in male rats. Biol Reprod 2009; 81: 1216-1225. [Medline] [CrossRef]

24. Ikegami K, Goto T, Nakamura S, Watanabe Y, Sugimoto A, Majarune S, Horihata K, Nagae M, Tomikawa J, Imamura T, Sanbo M, Hirabayashi M, Inoue N, Maeda KI, Tsukamura H, Uenoyama Y. Conditional kisspeptin neuron-specific Kiss 1 knockout with newly generated Kiss 1 -floxed and Kiss 1 -Cre mice replicates a hypogonadal phenotype of global Kiss 1 knockout mice. J Reprod Dev 2020; 66: 359-367.

25. Paxinos G, Franklin KBJ. The Mouse Brain in Stereotaxic Coordinates. San Diego, CA: Academic Press; 2008

26. Minabe S, Uenoyama Y, Tsukamura H, Maeda K. Analysis of pulsatile and surge-like luteinizing hormone secretion with frequent blood sampling in female mice. J Reprod Dev 2011; 57: 660-664. [Medline] [CrossRef]

27. Meistrich ML, Hess RA. Assessment of spermatogenesis through staging of seminiferous tubules. Methods Mol Biol 2013; 927: 299-307. [Medline] [CrossRef]

28. Minabe S, Ieda N, Watanabe Y, Inoue N, Uenoyama Y, Maeda KI, Tsukamura H. Long-term neonatal estrogen exposure causes irreversible inhibition of LH pulses by suppressing arcuate kisspeptin expression via estrogen receptors $\alpha$ and $\beta$ in female rodents. Endocrinology 2017; 158: 2918-2929. [Medline] [CrossRef]

29. Nakamura S, Ito Y, Yamamoto K, Takahashi C, Dai M, Tanahashi M, Uenoyama
Y, Tsukamura H, Oishi S, Maeda KI, Matsuda F. SB223412, a neurokinin-3 receptorselective antagonist, suppresses testosterone secretion in male guinea pigs. Theriogenol ogy 2017; 102: 183-189. [Medline] [CrossRef]

30. Merriam GR, Wachter KW. Algorithms for the study of episodic hormone secretion. Am J Physiol 1982; 243: E310-E318. [Medline]

31. Maeda KI, Tsukamura H, Uchida E, Ohkura N, Ohkura S, Yokoyama A. Changes in the pulsatile secretion of $\mathrm{LH}$ after the removal of and subsequent resuckling by pups in ovariectomized lactating rats. J Endocrinol 1989; 121: 277-283. [Medline] [CrossRef]

32. Clarke IJ, Li Q, Henry BA, Millar RP. Continuous kisspeptin restores luteinizing hormone pulsatility following cessation by a neurokinin B antagonist in female sheep. Endocrinology 2018; 159: 639-646. [Medline] [CrossRef]

33. George JT, Veldhuis JD, Roseweir AK, Newton CL, Faccenda E, Millar RP, Anderson RA. Kisspeptin-10 is a potent stimulator of LH and increases pulse frequency in men. J Clin Endocrinol Metab 2011; 96: E1228-E1236. [Medline] [CrossRef]

34. Higo S, Iijima N, Ozawa H. Characterisation of Kiss1r (Gpr54)-expressing neurones in the arcuate nucleus of the female rat hypothalamus. J Neuroendocrinol 2017; 29: 29 Medline] [CrossRef]

35. Dalkin AC, Haisenleder DJ, Ortolano GA, Ellis TR, Marshall JC. The frequency of gonadotropin-releasing-hormone stimulation differentially regulates gonadotropin subunit messenger ribonucleic acid expression. Endocrinology 1989; 125: 917-924. [Medline] [CrossRef]

36. Kaiser UB, Jakubowiak A, Steinberger A, Chin WW. Differential effects of gonadotropin-releasing hormone $(\mathrm{GnRH})$ pulse frequency on gonadotropin subunit and $\mathrm{GnRH}$ receptor messenger ribonucleic acid levels in vitro. Endocrinology 1997; 138: 1224-1231. [Medline] [CrossRef]

37. el-Safoury S, Bartke A. Effects of follicle stimulating hormone and luteinizing hormone on plasma testerone levels in hypophysectomized and in intact immature and adult male rats. J Endocrinol 1974; 61: 193-198. [Medline] [CrossRef]

38. Chan YM, Broder-Fingert S, Wong KM, Seminara SB. Kisspeptin/Gpr54-independent gonadotrophin-releasing hormone activity in Kiss1 and Gpr54 mutant mice. J Neuroendocrinol 2009; 21: 1015-1023. [Medline] [CrossRef]

39. Mayer C, Boehm U. Female reproductive maturation in the absence of kisspeptin/GPR54 signaling. Nat Neurosci 2011; 14: 704-710. [Medline] [CrossRef]

40. Popa SM, Moriyama RM, Caligioni CS, Yang JJ, Cho CM, Concepcion TL, Oakley AE, Lee IH, Sanz E, Amieux PS, Caraty A, Palmiter RD, Navarro VM, Chan YM, Seminara SB, Clifton DK, Steiner RA. Redundancy in Kiss1 expression safeguard reproduction in the mouse. Endocrinology 2013; 154: 2784-2794. [Medline] [CrossRef]

41. Krieger DT, Perlow MJ, Gibson MJ, Davies TF, Zimmerman EA, Ferin M, Charlto HM. Brain grafts reverse hypogonadism of gonadotropin releasing hormone deficiency. Nature 1982; 298: 468-471. [Medline] [CrossRef] 